Review

\title{
Selenium in Camel - A Review
}

\section{Bernard Faye $^{1, *}$ and Rabiha Seboussi ${ }^{2}$}

1 Département Environnement et Sociétés, CIRAD, Campus International de Baillarguet, UR 18, TA/C Dir B, 34398 Montpellier cedex, France

25902 Roi René Anjou, QC H1K3E7 Montréal, Canada; E-Mail: rseboussi@yahoo.com

* Author to whom correspondence should be addressed: E-Mail: faye@cirad.fr

Received: 11 May 2009 / Accepted: 5 July 2009 / Published: 8 July 2009

\begin{abstract}
Requirements for trace minerals in camels, particularly selenium, are not wellknown. Selenium supplementation using a pharmaceutical form or commercial mineral mixture is common practice in camels to address the cardiomyopathy often attributed to selenium deficiency. This supplementation is often empirical and based on estimated needs for cattle. Nowadays the use of selenium in animal foodstuffs is commonplace and further investigation of its metabolism (ingestion, dynamic of storage-destocking, excretion) in camels is warranted. The present review aimed to synthesize all the experimental research (comparative selenium status in cow and camel, response to different levels of supplementation at different physiological stages, excretion maternal transfer, experimental toxicosis) and field observations (deficiency, supplementation practices) undertaken in camels. The results underline the particularity of the unique metabolic profile of the camel and lead to practical recommendations for supplementation in camels, highlighting its relative sensitivity to excess $\mathrm{Se}$ intake at lower levels than in cattle. The maximal tolerable dose is $8 \mathrm{mg}$ and the recommended doses range from 2 to $4 \mathrm{mg}$.
\end{abstract}

Keywords: selenium; camel; requirements; deficiency; toxicity; excretion

\section{Introduction}

Camels have some physiological peculiarities in their trace element metabolism due to their adaptation to arid conditions and poor mineral feeding resources [1,2]. Some studies concerning trace elements such as copper, zinc, iron, manganese in camel have shown specific responses of this species 
to mineral supplementation or deficiencies. In general, the camel metabolism seems to anticipate mineral under-nutrition periods of its life with different mechanisms: increase of the absorption capacity in scarcity periods (copper, zinc) [3], higher storage capacity (copper) [4], tolerance for minerals and electrolytes in excess (calcium, phosphorus, sodium) [5,6], maintenance of enzymatic activity in deficient period (caeruloplasmin, superoxide-dismutase) $[7,8]$.

The adaptation to desert life means an addition of small metabolic improvements which provide no comparative advantage when they are considered one by one, but give a full meaning to the reputation of this species when they are considered as a whole. This probably explains why the camel is able to survive under desert conditions.

Concerning selenium, there is little evidence to date of clinical deficiencies or toxicities, and up to recently, few available data on selenium requirements and metabolism in this species. However, new findings on selenium metabolism in dromedary camel have been recently reported [9-13]. The present study aims at giving a progress report on current knowledge concerning the status of selenium and its metabolism in the dromedary based on all data available in the scientific literature.

\section{Normal Selenium Level in Camel Blood}

The mean concentration of blood/serum selenium reported in the literature for large animals was around $100 \mathrm{ng} / \mathrm{mL}$, a value considered as sufficient for the maintenance of suitable metabolic functions [14]. In the dromedary from Morocco, Hamliri et al. [15] observed in whole blood values between 109.1 and $117.8 \mathrm{ng} / \mathrm{mL}$, varying according to age and sex, being thus similar to those reported in sheep in the same area. Similar figures were recorded by Liu et al. [16] in China, with concentrations varying from 97 to $112 \mathrm{ng} / \mathrm{mL}$. In Sudan, Abdel Rahim [17] reported values in whole blood varying between 25 and $53 \mathrm{ng} / \mathrm{mL}$. Without specifying if it was whole blood or serum, Ma [18] reported higher values: 274 to $288 \mathrm{ng} / \mathrm{mL}$. The analytical method used could also explain the observed differences.

Serum concentrations approached these last figures: $281 \mathrm{ng} / \mathrm{mL}$ on average in sera coming from the Sultanate of Oman (Faye, unpublished data). In Morocco, in dromedaries receiving probably a low Se basal diet, the plasma selenium concentration was quite lower, about $21 \mathrm{ng} / \mathrm{mL}$ [19]. In male adult camels in healthy conditions from Iran, the selenium concentration reported in serum was $12.6 \mathrm{ng} / \mathrm{mL}$ only [20]. In Saudi Arabia, serum Se values reported in young camels at the slaughterhouse varied between 5.3 and $131 \mathrm{ng} / \mathrm{mL}$ with $30 \%$ of samples higher than $100 \mathrm{ng} / \mathrm{mL}$ [21]. In the United Arab Emirates (UAE), the mean value was $200 \pm 90 \mathrm{ng} / \mathrm{mL}$ in animals with no Se supplementation [22]. In recent experiments with different levels of Se supplementation, selenium content in serum for non-supplemented animals was on average $137.6 \pm 18.7 \mathrm{ng} / \mathrm{mL}$ in non-pregnant, non-lactating camels [9] (Seboussi et al., 2008), $109.3 \pm 33.1 \mathrm{ng} / \mathrm{mL}$ in pregnant females, and $103.4 \pm 28.7 \mathrm{ng} / \mathrm{mL}$ at milking period [11]. In small camelids such as llama [23], the selenium concentration in serum ranged on average between 213 and $203 \mathrm{ng} / \mathrm{mL}$ depending on the physiological status.

The variability was thus high and the range between 12 and $200 \mathrm{ng} / \mathrm{mL}$ with an average of $100 \mathrm{ng} / \mathrm{mL}$. However, in most of the reported values, the selenium status of the diet was unknown even if Se supplementation was not distributed to the animals. Also, the analytical procedures were not described in all the cases and could differ between authors. 


\section{Selenium Deficiency}

For a long time, selenium deficiency has been suspected to occur in camels kept in zoological parks affected by cardiopathy or myopathy [24-26], but no clinical descriptions and laboratory analysis have been made in these reports to confirm the role of selenium. Also, in China Liu et al. [16] suspected selenium deficiency in cases of sway-back in Bactrian camel. However, selenium deficiency with characteristic clinical signs has been recently reported. Selenium deficiencies affect generally young animals and are responsible for white muscle disease. The most important lesions are degenerative myocarditis and discoloration of skeletal muscle. In the UAE, soils and feedstuffs are generally considered deficient in selenium, and many cases of degenerative myocarditis (Figure 1) are observed with histological lesions similar to those in cattle $[22,27]$.

Figure 1. Degenerative myocarditis lesions in the heart of a one-month old camel calf (Photo: R. Seboussi).

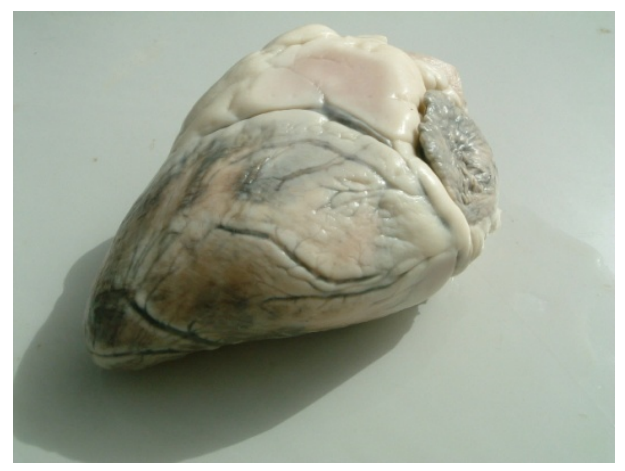

When the skeletal muscles are affected, symptoms vary from mild stiffness to obvious pain upon walking, to an inability to stand. Camel calves may tremble in pain when held in a standing position. When the problem occurs in newborns - they are born weak and unable to rise. Sudden exercise may trigger the condition in older camel calves. When the disease affects the heart, the animal shows signs similar to pneumonia, including difficult breathing, fever with an elevated heart and respiratory rates.

In sick animals, between 2 and 12 weeks old, remarkable signs of anemia were observed with reduction of hemoglobin concentration, slight decline of $\mathrm{PCV} \%$ and total erythrocytes comparing to the normal levels reported in apparently healthy animals of the same age [27], but these findings were not observed in three seleno-deficient adult camels from Saudi Arabia [28]. The histopathological findings showed alterations of the cardiac tissue with focal areas of non-inflammatory coagulative necrosis. The necrotic areas showed swollen myocardial fibers with granular cytoplasm and loss of striation. This was accompanied by severe blood vessels congestion, edema and lymphocytic infiltration. Calcium salt deposition was observed all over the necrotic area and fibrous area also [27].

The serum selenium level in deficient camels was obviously very low: in camel calves, the average level of Se serum in diseased cases was below $35 \mathrm{ng} / \mathrm{mL}$ [27] (and between 0.8 and $3.7 \mathrm{ng} / \mathrm{mL}$ in 3-yr animals [28]. 


\section{Effect of Se Supplementation on Se Status in Camel}

Few papers relate the impact of selenium complementation on the mineral status of camel and, generally, the doses applied for selenium deficiency control were those recommended for cattle. To our knowledge, the first trial achieved to assess the effect of selenium supplementation on the plasma selenium status was reported by Bengoumi et al. [19]. These authors compared the selenium status of camels with that of cattle with similar weight and receiving daily $2 \mathrm{mg}$ Se per os in sodium selenite form for two months. In this study, sharper increase of plasma selenium occurred in camels (10 times the plasma level before supplementation) compared to cows (twice the starting level) was observed (Figure 2). As the magnitude of the decrease of plasma selenium concentration after stopping supplementation was similar to the previous increase, it was supposed that plasma (or serum) selenium concentration in camel was an extremely sensitive indicator of selenium intake. The fast selenium depletion at the end of the supplementation period seemed also to indicate a better efficiency of selenium absorption and excretion in camel compared to cow.

Figure 2. Comparative change in plasma selenium concentration in cow (•) and dromedary camel (o) receiving $2 \mathrm{mg}$ /day selenium under sodium selenite form (reproduced from [19], with permission).

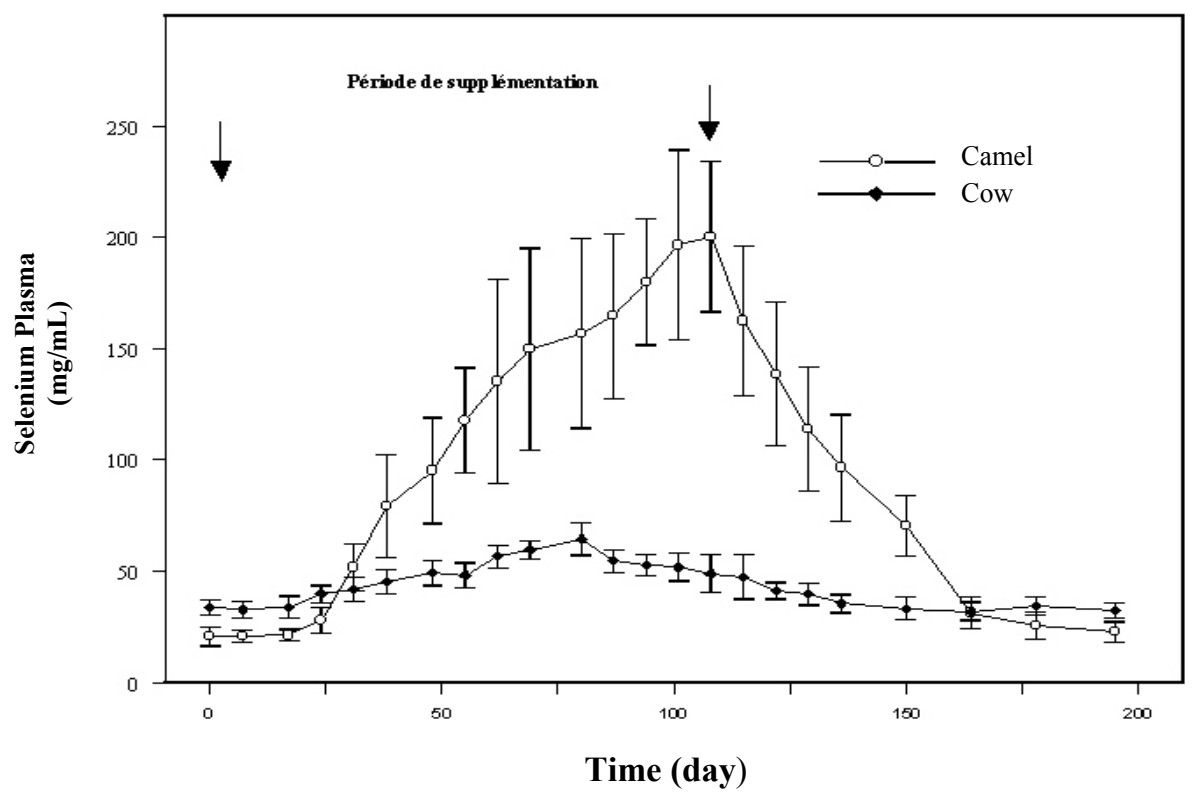

In selenodeficient camels with muscular dystrophy, Al-Qarawi et al. [28] gave an oral treatment involving selenium - vitamin E (Bo-SE, Schering - Plough Animal Health, $2.19 \mathrm{mg}$ sodium selenite $+50 \mathrm{mg}$ vitamin E) by IM injection at a dose rate of $0.5 \mathrm{mg} / \mathrm{kg}$ body weight for two consecutive days. Following treatment, selenium concentration rose from on average $2.3 \mathrm{ng} / \mathrm{mL}$ up to $23.7 \mathrm{ng} / \mathrm{mL}$, i.e., with a similar trend to that observed by Bengoumi et al. [19], who also observed that the selenium concentration was increased 10 -fold after supplementation.

In several studies on the effect of oral selenium supplementation [9,11-13,22], different levels of supplementation were tested up to the toxic limit, from 2 up to $16 \mathrm{mg} /$ day under sodium selenite form. 
In the first experiment, 12 non-pregnant and non-lactating female camels shared into three groups received, after a two-week adaptation period, an oral Se supplementation (0,2 and $4 \mathrm{mg}$, respectively) under sodium selenite form for three months. Feed intakes were assessed daily, blood samples and body weight were taken weekly, feces and urine samples were collected every two weeks up to one month after the end of the supplementation period. The Se concentration in serum had increased significantly in supplemented groups (Figure 3). The maximum level was observed in the period of supplementation in the camel receiving $4 \mathrm{mg}(492.5 \mathrm{ng} / \mathrm{mL})$, which was 4 -fold compared to the value at the beginning of the trial (126 to $138.5 \mathrm{ng} / \mathrm{mL}$ depending on the groups).

Figure 3. Change in serum Se (in $\mathrm{ng} / \mathrm{mL}$ ) concentration in non-pregnant and non-lactating camels according to the Se supplementation level: $0(\mathbf{\square}), 2(\boldsymbol{\Delta})$ and $4(\diamond) \mathrm{mg}$ daily by period*treatment (reproduced from [9], with permission).

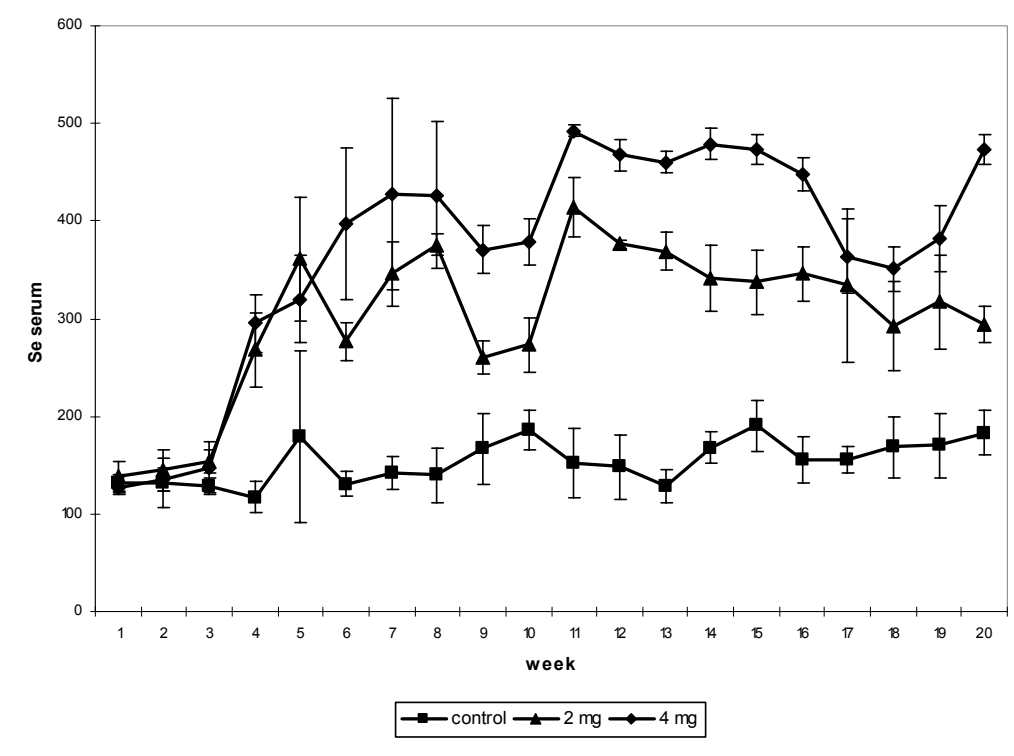

In the second experiment, 12 pregnant females, divided into two groups, received 0 and $2 \mathrm{mg} \mathrm{Se}$ respectively in sodium selenite form at the end of their gestation (last three months) and for up to one month at the beginning of their lactation. The supplementation was stopped after one month of lactation. As for the previous experiment, feces and urine samples were collected every two weeks. The mean value of selenium content in serum was significantly higher in supplemented group ( $2 \mathrm{mg}$ ) and was three-fold higher than the concentration compared to the control group $(305.9 \pm 103.3 \mathrm{ng} / \mathrm{mL}$ and $109.3 \pm 33.1 \mathrm{ng} / \mathrm{mL}$ respectively). The maximum level was observed two weeks before calving in the group receiving $2 \mathrm{mg}(638.7 \mathrm{ng} / \mathrm{mL})$. The selenium level at parturition was still significantly higher in the treated group in spite of a slight decrease around the calving period (Figure 4). On average, serum Se concentration in control and treated groups was significantly higher after parturition (121.6 and $349.7 \mathrm{ng} / \mathrm{mL}$, respectively) than before (97.4 and $272.7 \mathrm{ng} / \mathrm{mL}$ respectively) in spite of stopping supplementation in the treated group. 
Figure 4. Biweekly changes (mean and S.E) in serum selenium concentration (in $\mathrm{ng} / \mathrm{mL}$ ) in camels before and after parturition according to the selenium supplementation level, $0 \mathrm{mg} /$ day $(\boldsymbol{\Delta})$ and $2 \mathrm{mg} /$ day $(\bullet)$ (reproduced from [11], with permission).

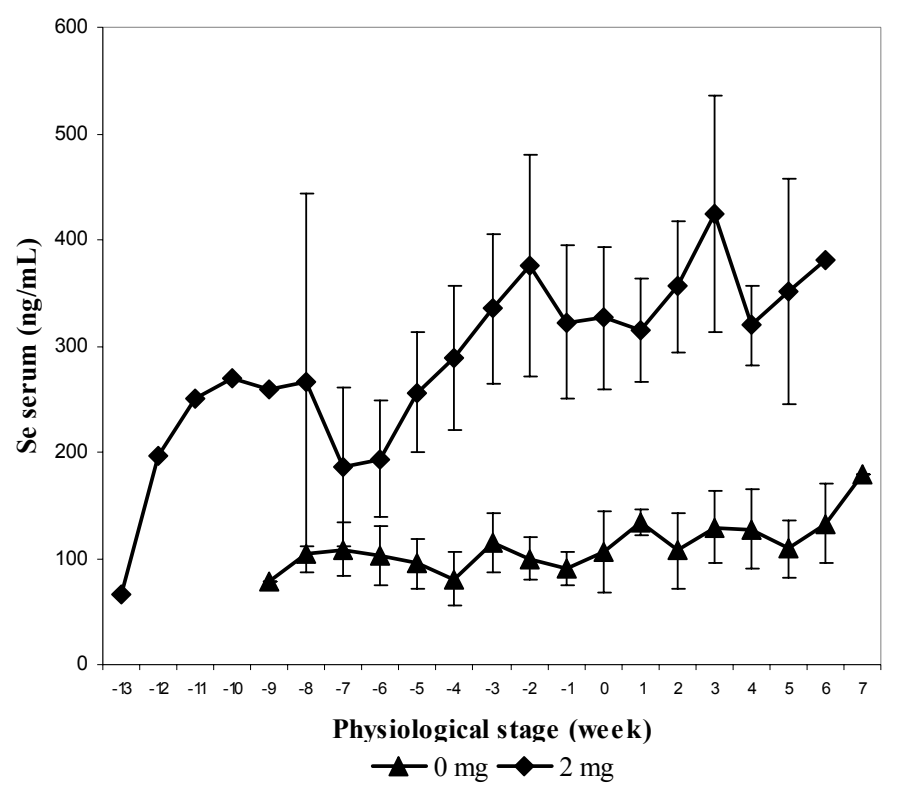

Figure 5. Weekly change in serum selenium according to Se supplementation in the basal diet of camels, $0 \mathrm{mg} /$ day $(\bullet), 2 \mathrm{mg} /$ day $(\bullet), 4 \mathrm{mg} /$ day $(\boldsymbol{\Delta})$ and $8 \mathrm{mg} /$ day $(\boldsymbol{\bullet})$ (reproduced from [13], with permission).

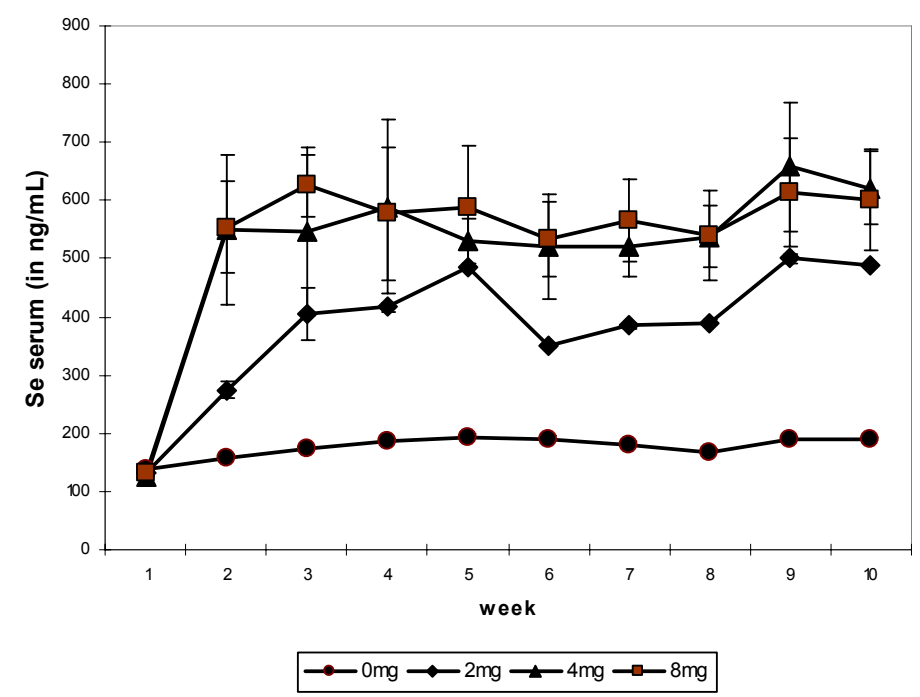

In the third experiment, eight young female camels shared into four groups of two 2-y old ones received a basal diet enriched with $0,2,4$ and $8 \mathrm{mg}$ selenium in sodium selenite form for 64 days. On average, the mean value of selenium in the serum was $176.3 \pm 18.0 \mathrm{ng} / \mathrm{mL}$ in the control group, $382.7 \pm 107.6 \mathrm{ng} / \mathrm{mL}$ in the group receiving $2 \mathrm{mg} \mathrm{Se}, 519.8 \pm 168.4 \mathrm{ng} / \mathrm{mL}$ in the group receiving $4 \mathrm{mg}$ Se and $533.4 \pm 158.6 \mathrm{ng} / \mathrm{mL}$ in group receiving $8 \mathrm{mg}$ Se daily. The weekly change showed a significant increase $(P<0.001)$ from week 2 up to the end of the experiment in the three supplemented groups compared to the control one (Figure 5). There was no difference between the groups receiving 
4 and $8 \mathrm{mg}$ Se. The maximum value $(657.3 \mathrm{ng} / \mathrm{mL})$ was observed in group 3 at week 9 and the minimum at the beginning of the experiment (124.1 $\mathrm{ng} / \mathrm{mL}$, also in group 3).

In the fourth experiment, the quantity of supplied selenium throughout the trial (90 days) was for each group of four camels, 2-year old, respectively $8 \mathrm{mg}$ (i.e., $17.44 \mathrm{mg}$ sodium selenite), $12 \mathrm{mg}$ (i.e., $26.16 \mathrm{mg}$ sodium selenite) and $16 \mathrm{mg}$ (i.e., $34.88 \mathrm{mg}$ sodium selenite) daily. Selenium supplementation was stopped immediately at the time of apparition of chronic selenosis and hepatoprotector was given to prevent death. Camels returned to normal good health gradually. On average the mean value of selenium in serum was $358.3 \pm 210.8 \mathrm{ng} / \mathrm{mL}(\mathrm{n}=69)$ and varied between 16.3 and $899.8 \mathrm{ng} / \mathrm{mL}$. The mean values of selenium in serum were $321.2 \pm 140.5 \mathrm{ng} / \mathrm{mL}$ in group 1 ( $8 \mathrm{mg} \mathrm{Se}), 443.2 \pm 231.1 \mathrm{ng} / \mathrm{mL}$ in group $2(12 \mathrm{mg} \mathrm{Se})$ and $298.04 \pm 212.13 \mathrm{ng} / \mathrm{mL}$ in group $3 \mathrm{receiving}$ $16 \mathrm{mg}$ Se daily. The bi-weekly change showed a significant increase $(\mathrm{P}>0.001)$ from fortnight 2 up to the end of the experiment for groups 1 and 2 and up to fortnight 3 for group 3 with a value of $767.15 \mathrm{ng} / \mathrm{mL}$. Serum Se concentration decreased significantly in fortnight 4 in group 3 up to the end of the trial to reach a value of $129.86 \mathrm{ng} / \mathrm{mL}$ when Se supplementation was stopped when selenosis symptoms appeared (Figure 6). The maximum observed value was $899.87 \mathrm{ng} / \mathrm{mL}$.

Figure 6. Changes in serum Se concentrations according to the selenium supplementation level in camels (Mean and S.E) at $8(\bullet), 12(\boldsymbol{\Delta})$ and $16 \mathrm{mg} /$ day $(\bullet)$. The * points to the Se supplementation stopping in group 3 (reproduced from [11], with permission).

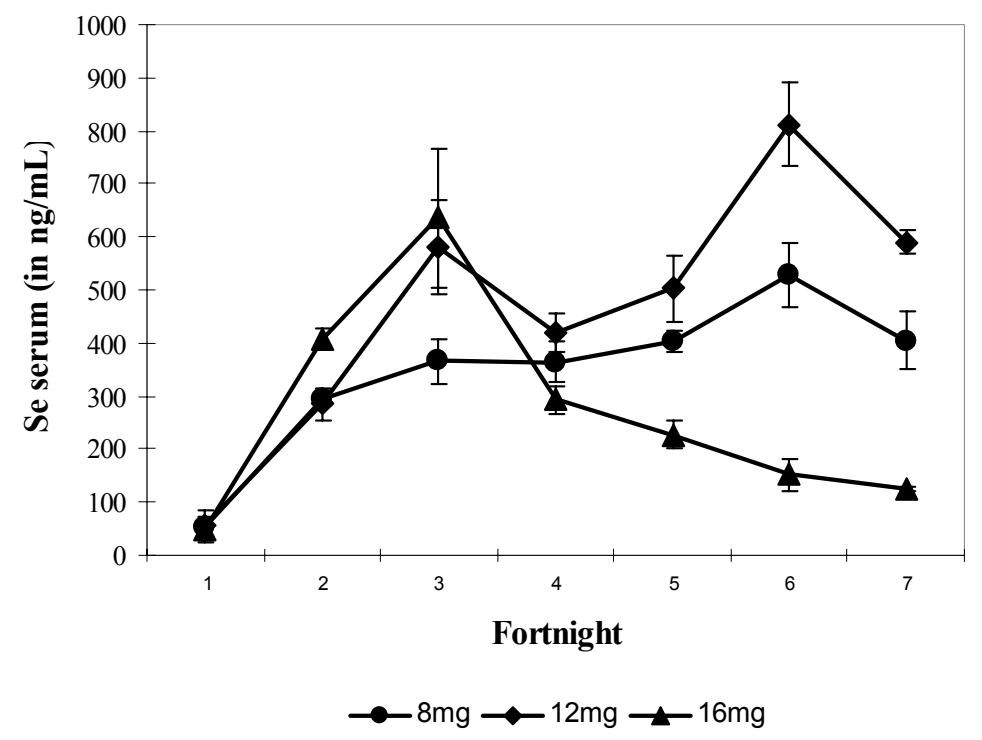

A meta-analysis of the data including oral supplementation from 0 to $16 \mathrm{mg} /$ day (only values after at least one week of supplementation were taken into account) showed a clear linear relationships up to $4 \mathrm{mg}$, then a slight increase with a plateau after $12 \mathrm{mg}$ /day (Figure 7). 
Figure 7. Change in camel serum selenium according to the level of oral supplementation (according to [9], [11] [12] and [13]).

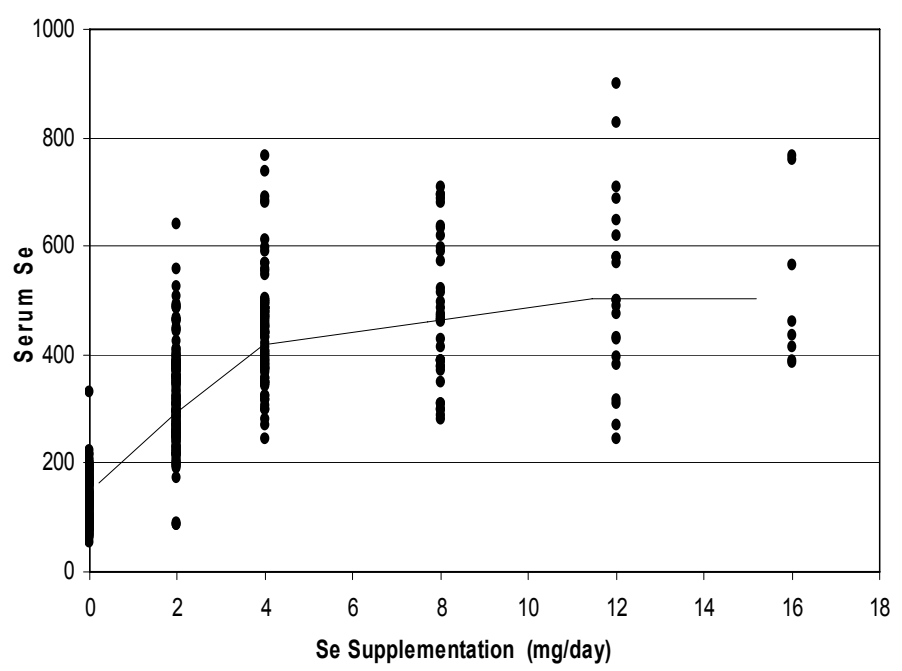

\section{Maternal Transfer of Se}

In the previous experiment on lactating camels [11], Se was determined in camel calves after birth and in milk. Se supplementation involved dams only. Se serum concentrations in camel calves at parturition were $106.3 \pm 26.5$ and $273.2 \pm 48.0 \mathrm{ng} / \mathrm{mL}$, in the control $(0 \mathrm{mg} / \mathrm{day})$ and treated groups ( $2 \mathrm{mg} /$ day), respectively. This significant difference $(P<0.001)$ was maintained for the entire milking period: $103.4 \pm 28.7$ and $248 \pm 14.1 \mathrm{ng} / \mathrm{mL}$ in the control and treated groups, respectively.

In milk, the Se concentration varied from 39.5 to $482.6 \mathrm{ng} / \mathrm{mL}$, with an average of $86.4 \pm 39.1 \mathrm{ng} / \mathrm{mL}$ in the control group and $167.1 \pm 97.3 \mathrm{ng} / \mathrm{mL}$ in the treated group. At birth, Se concentration in colostrum was three-fold higher in the treated group: mean value $302 \pm 94.60 \mathrm{vs}$ $108.2 \pm 43.9 \mathrm{ng} / \mathrm{mL}(P<0.001)$. In both groups, Se milk concentration decreased and after the second milk sampling, no significant difference was observed (Figure 8). By considering Se concentration in colostrum and the status of the mothers and of their camel calves at parturition, positive correlations were observed with serum Se in mothers $(\mathrm{r}=0.659 ; P<0.05)$ and in calves $(\mathrm{r}=0.689 ; P<0.05)$.

The reported values of selenium in camel milk are quite scarce. Al-Awadi and Srikunar [29] reported a much lower value $(13.9 \pm 2.4 \mathrm{ng} / \mathrm{mL})$ than Seboussi et al. [11], but the former did not mention the lactation stage. In a meta-analysis performed on cattle's data [30], it has been considered that the selenium increase in milk was on average $12.6 \mathrm{ng} / \mathrm{mL}$ only after oral Se supplementation at a dose of less than $3 \mathrm{mg} /$ day under selenite form. In comparison, the apparent good efficiency of Se transfer in camel milk has to be confirmed. 
Figure 8. Biweekly changes (mean and S.E) in milk selenium concentration (in $\mathrm{ng} / \mathrm{mL}$ ) in she-camels for the three first months of lactation according to the selenium supplementation level: $0 \mathrm{mg} /$ day $(\boldsymbol{\Delta})$ and $2 \mathrm{mg} /$ day $(\bullet)$ (reproduced from [11], with permission).

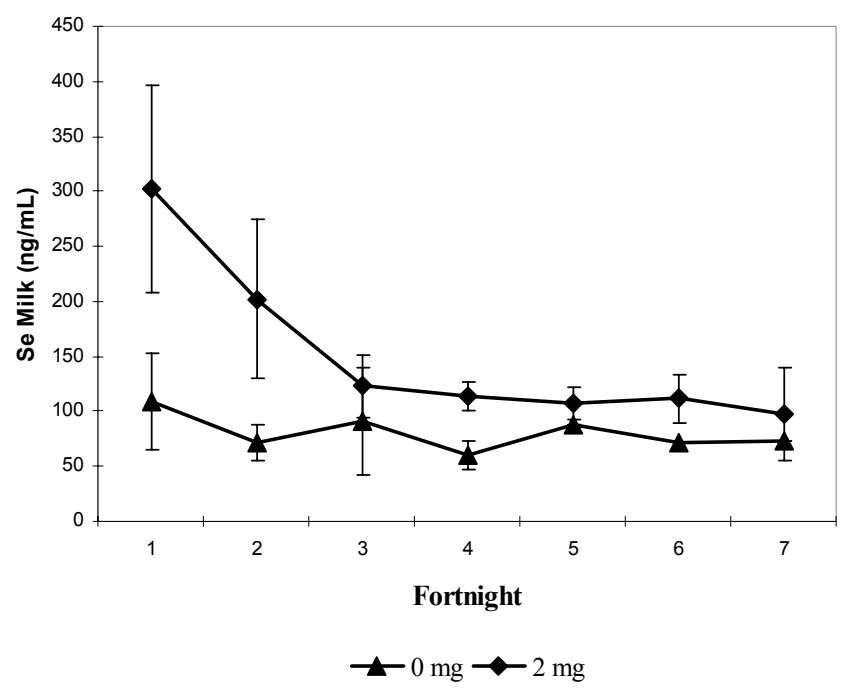

\section{Correlations of Selenium with GSH-Px Activity and Vitamin E}

For its transport in blood, selenium is linked to specific proteins (selenoproteins), including glutathione peroxidase (GSH-Px). In the comparative study of Bengoumi et al. [19], the increase of GSH-Px activity was similar in camels and cows for the supplementation period with a higher correlation in camels $(r=0.94)$ than in cows $(r=0.68)$. As for other species, GSH-Px is a good indicator of the Se status of camel. However, after the end of the supplementation, GSH-Px activity continued to increase in camels' blood while it was stable in cows' (Figure 9). A similar figure was observed by Seboussi et al. [9].

Figure 9. Comparative change in GSH-Px activity in cows (•) and dromedary camels (o) receiving $2 \mathrm{mg}$ /day selenium under sodium selenite form (reproduced from [19], with permission).

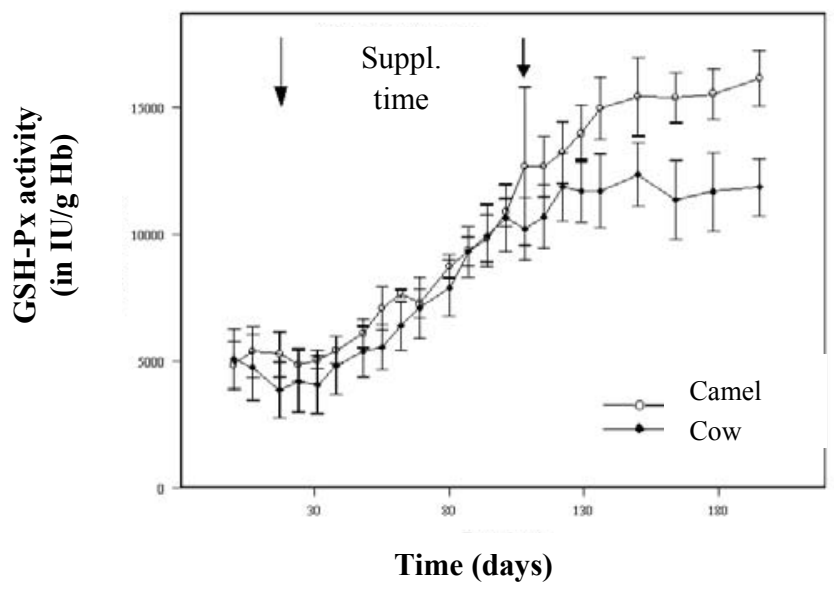


This increase could be explained by the maintenance of the biosynthesis induction in the camel erythrocytes from the selenium probably stored in the erythrocytes, and a longer plasmatic half-life of GSH-Px compared to those of cattle. In fact, the erythrocyte GSH-Px activity being closely related to the half-life to the red blood cells, the enzymatic activity was higher in camels than in cows when selenium was depleted because of the longer survival of camel erythrocytes [31]. The linear relationship between erythrocyte GSH-Px and whole blood Se concentration was described in camesl by several authors [9-13,15,17,32] but with variable correlation coefficients (Figure 10).

Figure 10. Relationship between Se serum and GSH-Px in camels according to data metaanalysis of [9], [11] [12] and [13]).

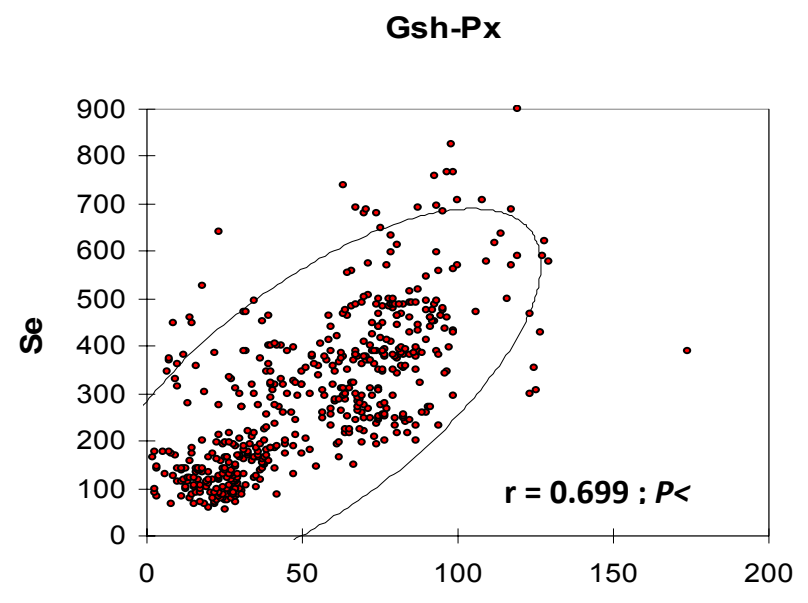

Vitamin $\mathrm{E}$ is an essential component in the reproduction processes and performance of farm animals and acts in synergy with selenium (Se), especially in order to prevent white muscle disease (WMD) due to a severe deficiency. In the literature on camel from the UAE, the mean values were $1.13 \pm 0.61 \mu \mathrm{g} / \mathrm{mL}$ (non-lactating and non pregnant), $1.12 \pm 0.81 \mu \mathrm{g} / \mathrm{mL}$ (pregnant), $1.20 \pm 0.80 \mu \mathrm{g} / \mathrm{mL}$ (lactating), $0.82 \pm 1.06 \mu \mathrm{g} / \mathrm{ml}$ (new-born), $0.56 \pm 0.22 \mu \mathrm{g} / \mathrm{mL}$ (young 2-y old) and $0.68 \pm 0.36 \mu \mathrm{g} / \mathrm{mL}$ (Se intoxicated young camels) [9-13]. These results were quite similar to those described in young camels from Sudan $(0.3$ to $1.65 \mu \mathrm{g} / \mathrm{mL})$ [33]. Similar results were reported by AlSenaidy [34] and Mousa et al. [35]. In all the cases where serum Se and vitamin E were analyzed, no correlation was observed [10-12]. In case of Se intoxication, a tendency to the decrease of vitamin E in intoxicated animals with clinical signs was observed but no significant correlation was reported with serum Se concentration $[10,12,13]$.

\section{Se Excretion}

Very few data are available on fecal and urinary Se excretion in camel. According to the different trials reported above [9,11-13] with variable levels of Se supplementation in the diet, Se fecal excretion increased slowly up to $4 \mathrm{mg}$ Se in the diet, then highly from $8 \mathrm{mg}$ daily supplementation up to $16 \mathrm{mg}$ (Figure 11). The total fecal excretion varied from $637.9 \mathrm{ng} /$ day in non-supplemented camels up to $4,084.4 \mathrm{ng} /$ day in camels receiving $16 \mathrm{mg}$ Se/day in the diet. The total fecal excretion was comparable to urinary excretion when administering up to $4 \mathrm{mg}$ supplementation, but the main part of 
Se excretion after $8 \mathrm{mg}$ of supplementation was of fecal origin. The total urinary excretion varied from $518.5 \mathrm{ng} /$ day (control groups) up to $1,795.9 \mathrm{ng} /$ day (16 mg Se supplemented group). Forty-five percent of the excreted $\mathrm{Se}$ was from urine in non-supplemented animals vs 26-30\% only in highly supplemented camels. Similar trends were observed with Se concentration in feces. Moreover, Se concentration in serum was highly correlated with Se concentration in urine and with fecal concentration and total Se fecal excretion but not with total urinary excretion (Figure 11).

Similar change in Se excretion was observed in cattle [36]. When the dietary intake was increased from 0.15 to $0.40 \mathrm{mg} / \mathrm{kg} \mathrm{DM}$ in cattle, the selenium concentration in feces and urine increased significantly from 370 to $780 \mathrm{ng} / \mathrm{g} \mathrm{DM}$ and from 20 to $180 \mathrm{ng} / \mathrm{mL}$, respectively [36], close to the results from Seboussi et al. [11]: on average 225 and $817 \mathrm{ng} / \mathrm{g}$ in the control and the treated group, respectively. But, contrary to this former observation achieved in dairy cattle, no linear effect was observed in camel.

Figure 11. Fecal and urine excretion of selenium according to the level of supplementation (data meta-analysis of [9], [11] [12] and [13]).

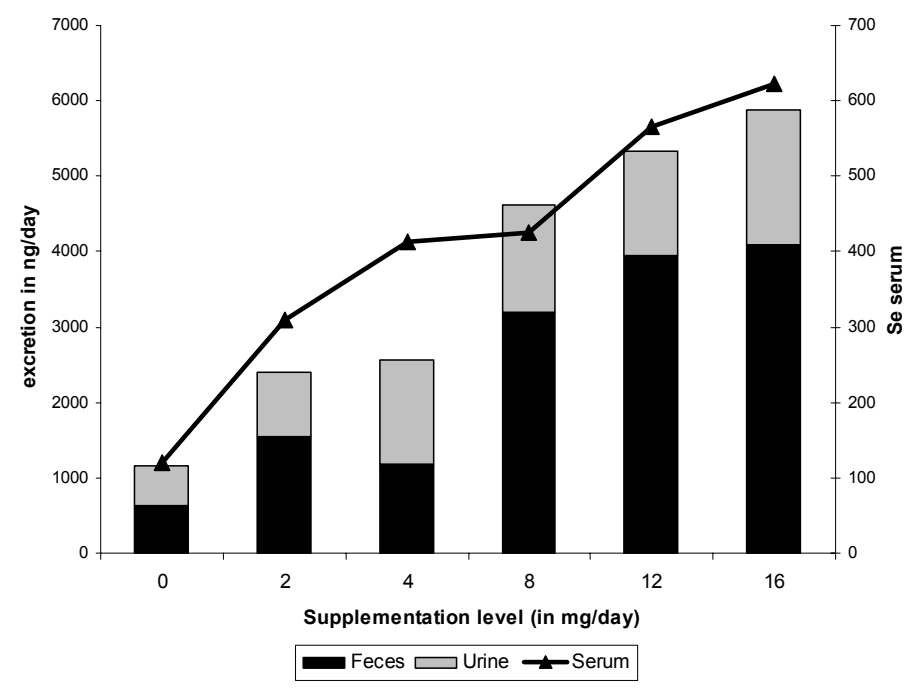

The urinary selenium concentration is considered to be a more sensitive indicator of sodium selenite consumption than nutritional requirements [37]. Elsewhere, the camel is well-known for its water metabolism and its ability to excrete a more concentrate urine although the watering was ad libitum in the mentioned trials. The high Se urinary concentration, particularly in camels receiving Se in their diet, compared to cattle, seems to demonstrate a peculiar sensitivity to Se supplementation.

\section{Se Storage in Organs}

Selenium determination in organs has rarely been reported because it is of little clinical interest. In the wool of Bactrian camel from China, Liu et al. [16] reported values between 140 and $190 \mu \mathrm{g} / \mathrm{kg}$, depending on their physiological status. Similar results have been published by Ma [18]: 190 to $210 \mu \mathrm{g} / \mathrm{kg}$. These values corresponded to camels receiving $2 \mathrm{mg}$ Se supplementation in the experiment of Faye and Seboussi [13] $(163.6 \mu \mathrm{g} / \mathrm{kg})$. In lambs, the wool Se concentration varied between 500 and $2,500 \mu \mathrm{g} / \mathrm{kg}$, depending on the dietary Se level [38]. Part of the selenium ingested is involved in hair 
amino acids synthesis. It was suggested that a level of selenium content should be higher than $120 \mathrm{ppm}$ in cow and calf hair to avoid nutritional myopathy. Season, color of hair, age and sex, affect the selenium content in hair. The selenium concentration was higher in winter than in summer and in dark color hair than in light color hair [39]. Hair appeared as the most sensitive organ to Se supplementation as it was reported on lamb [39] and cattle [40]. However, as with other minerals, the selenium concentration in hair is of limited interest [41].

In the experiments of Faye and Seboussi [13], Seboussi et al. [9,11,12], and Seboussi [42], on average the highest total quantity of selenium was observed in the following order: in the liver $(2727 \mu \mathrm{g})$, the kidney $(807 \mu \mathrm{g})$, the lung $(443 \mu \mathrm{g})$ and the heart $(160 \mu \mathrm{g})$. Of course, a high quantity was also observed in muscle $(2,513 \mu \mathrm{g})$. On average, whatever the Se supplementation level, the kidney $(1,129 \mu \mathrm{g} / \mathrm{kg})$, the liver $(921 \mu \mathrm{g} / \mathrm{kg})$, the hair $(545 \mu \mathrm{g} / \mathrm{kg})$, the forelimb muscle $(421 \mu \mathrm{g} / \mathrm{kg})$, the hind limb muscle $(351 \mu \mathrm{g} / \mathrm{kg})$ and the lung $(308 \mu \mathrm{g} / \mathrm{kg})$ had the highest Se concentrations. The total quantity was higher in supplemented groups but, except in hair, liver, kidney and muscle, the quantity was not clearly linked to the Se supplementation level. By giving an index of 100 for concentrations in animals receiving $0 \mathrm{mg}$ Se supplementation, the main organs where selenium was stored were hair, liver and muscles, and to a lesser extent lung, ovary and pancreas (Figure 12). In Bactrian camel, one reference only was available for selenium concentration in organs [18]. In this study, kidney (3,100 to $3,900 \mu \mathrm{g} / \mathrm{kg}$ ), liver, and heart (1,100 to $1,500 \mu \mathrm{g} / \mathrm{kg})$, muscle and brain (620 to $640 \mu \mathrm{g} / \mathrm{kg}$ ) were the organs with the highest Se concentrations. These values, except those of the liver, appeared much higher than those found by Seboussi et al. $[11,12]$.

Figure 12. Selenium concentration index in the different camel organs according to the Se supplementation level in the diet. The index 100 corresponds to Se concentration for $0 \mathrm{mg}$ supplementation (data meta-analysis of [9], [11] [12] and [13]).

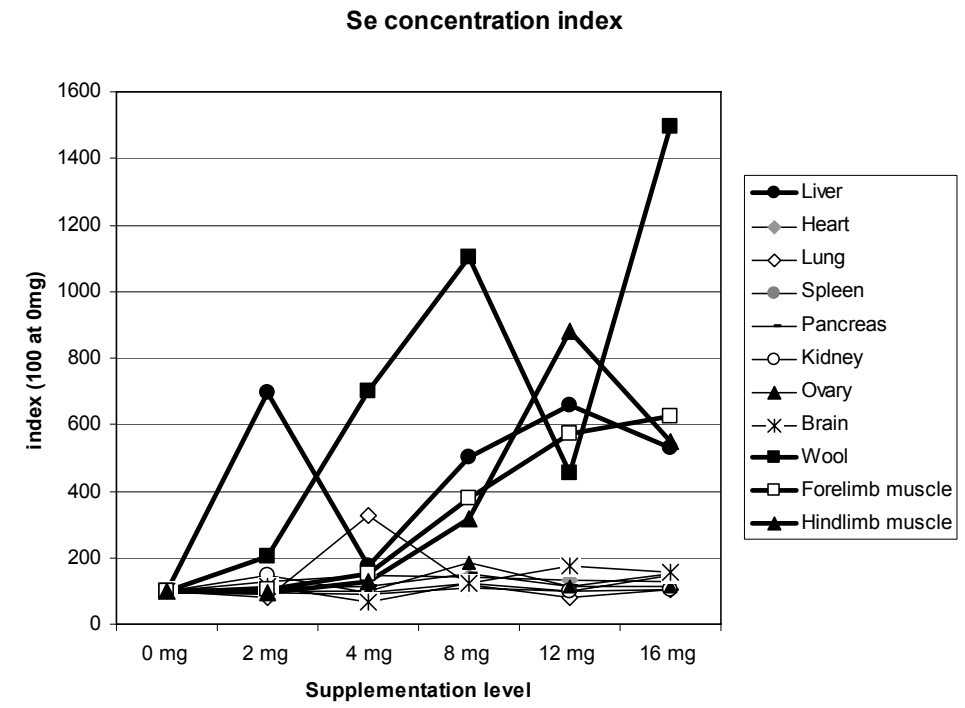

In the selenium tolerance trial carried out in lamb [38], the liver had the highest Se concentration (up to $2,000 \mu \mathrm{g} / \mathrm{kg}$ ), followed by the kidney (around $1,000 \mu \mathrm{g} / \mathrm{kg}$ ). In another study on sheep, selenium was found in the highest concentrations in the kidney, followed by the liver, pancreas, heart and skeletal muscle [41]. No linear trend of liver Se concentrations according to the Se supplementation 
level was observed in lamb [38]. In calves receiving $3 \mathrm{ppm}$ dietary Se treatment, Se concentrations were $4,740 \mu \mathrm{g} / \mathrm{kg}$ in liver, 3,420 in kidney, 1,380 in heart and 340 in muscle [43]. Contrary to Cristaldi et al. [38], a regular increase of Se concentration with dietary Se level was observed by these authors. According to them, the kidney was the major organ involved in the storage of selenium at low Se supplementation, but at high intakes, the liver became the target organ [43,44]. Similar figures could be observed with camel [13].

However, considering the weight of whole carcass and of the different organs in camel, the total quantity of selenium in a camel of $200 \mathrm{~kg}$ carcass weight was around $100 \mathrm{mg}$ with $90 \%$ in the muscle, $5.5 \%$ in the blood and $2.5 \%$ in the liver. Less than $1 \%$ was stored in the kidney.

\section{Se Toxicity}

At our knowledge, only experimental selenosis has been reported [10,13,43]. The first clinical disturbances appeared with a selenium supplementation of $8 \mathrm{mg} /$ day. The first physiological symptoms were an increase of the respiratory rate, pulse rate, and internal temperature up to $40{ }^{\circ} \mathrm{C}$.

The clinical signs occurred within two weeks, with hair discoloration, followed by alopecia, more severe in animals receiving a higher quantity of selenium (up to $16 \mathrm{mg} /$ day). Enlargement of the inferior cervical lymph node was seen in all intoxicated animals. Camels tended to sit alone. Urinary excretion increased and dark watery diarrhea was also observed. Loss of appetite, thus loss of weight and weakness appeared. Tears with pale mucous were present as well as evidence of impaired vision. Dyspneic respiration and pain at auscultation appeared and camels adopted the sternal decubitus position and tended to rest their neck extended (Figure 13). Salivation occurred and finally camels showed no desire to eat and drink. The tail was elevated. Fissured pads appeared in all groups but more pronounced in groups receiving 12 and $16 \mathrm{mg}$. Consequently, camels had difficulty in walking (Figure 14).

Figure 13. Camel in sternal decubitus position with neck extended on ground. (Seboussi, [42]).

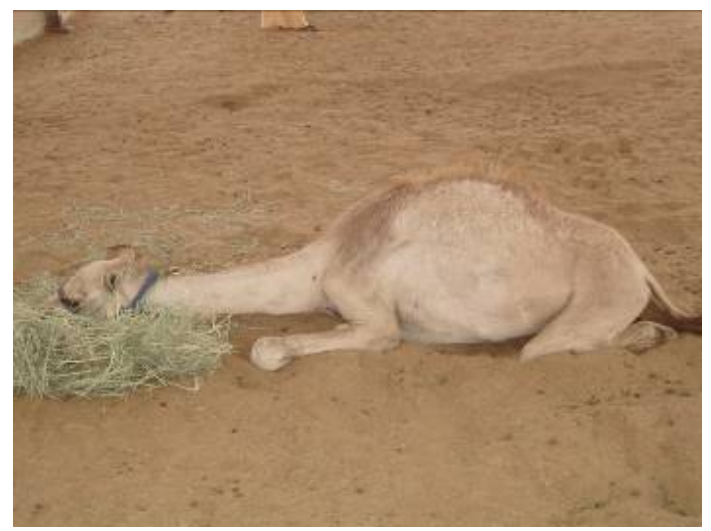


Figure 14. Fissured pads with necrosis on foot of camel receiving $16 \mathrm{mg} \mathrm{Se}$ /day (Seboussi, [42]).

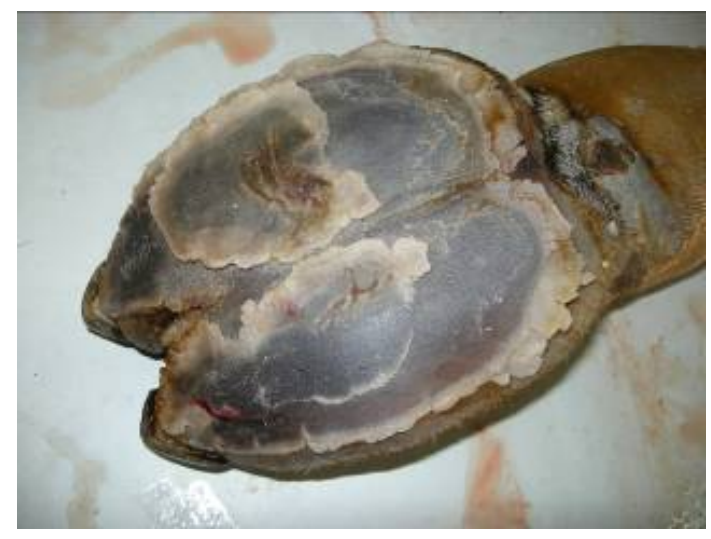

After slaughter, intoxicated camels showed paleness in all abdominal muscles (Figure 15), paleness of diaphragm and intercostal muscles, hydrothorax, pulmonary emphysema. The texture of the liver and lung was not uniform. Heart, liver and kidney were congested and necrosed.

Figure 15. Discoloration of the red muscle in Se intoxicated camel receiving $16 \mathrm{mg}$ Se daily (Seboussi, [42]).

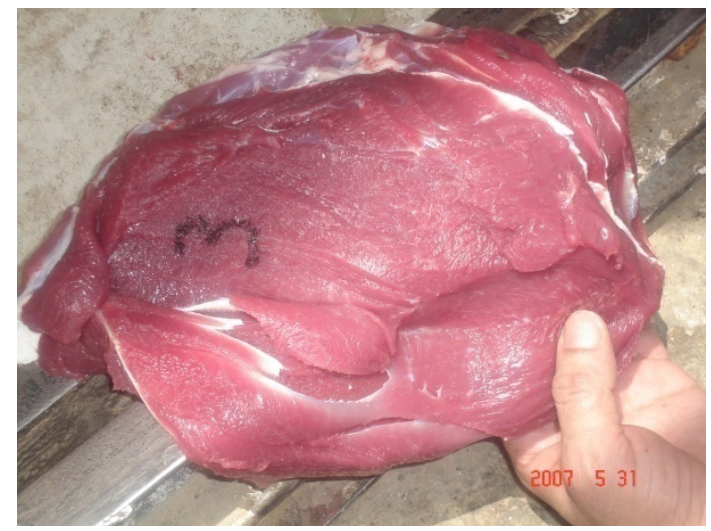

Figure 16. Heart discoloration and congestion in camel receiving $8 \mathrm{mg}$ selenium per day for 45 days (Seboussi, [42]).

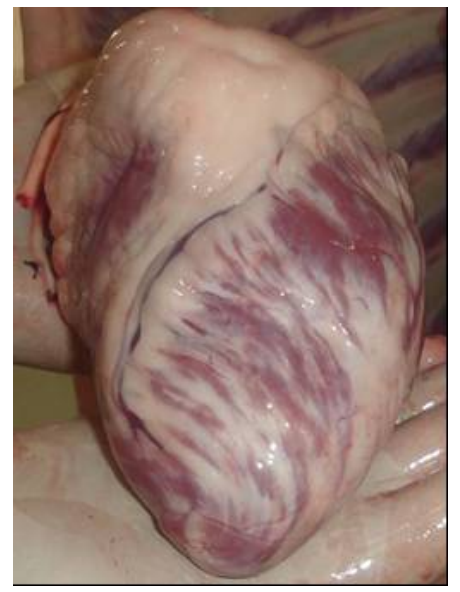


In addition to prior lesions, camels showed a flap heart with necrosis and congestion (Figure 16). However, the heart was partially white (fibrosis), congested and necrosed in camel receiving $8 \mathrm{mg}$. Hepatomegaly was observed in all animals, while pancreas was atrophied. Brain edema was also observed.

Histopathology lesions involved all the organs, and the lesions increased with the quantity of selenium in the diet. Kidneys showed eosinophilic granulated material in diluted Bowman's space and convoluted tubules in addition to degenerative changes in epithelial lining cells. The heart showed proliferation of Purkinje fibers, capillaries congestion in Purkinje fiber tissues and sub-endocardial tissues, degenerative changes in myofibers. The cardiac tissues showed edematous fluid between more eosinophilic thick myocardial fibers (Figure 17). Vacuolar degenerative changes were observed all over the hepatic cells of the hepatic lobules, as well as congestion in central hepatic vein and hepatic sinusoids (Figure 18). In addition, focal areas of muscular hyalinization (non-inflammatory) and edema were observed in intercostal and diaphragm muscles. In addition focal coagulative necrosis areas appeared in pancreatic acinis. Hyaline degeneration of myofibers and edema was also observed in shoulder and intercostal muscles. The brain showed perivascular edema.

Figure 17. Congestion of the capillary vessels in the camel heart in camel receiving $12 \mathrm{mg} \mathrm{Se} /$ day (Seboussi, [42]).

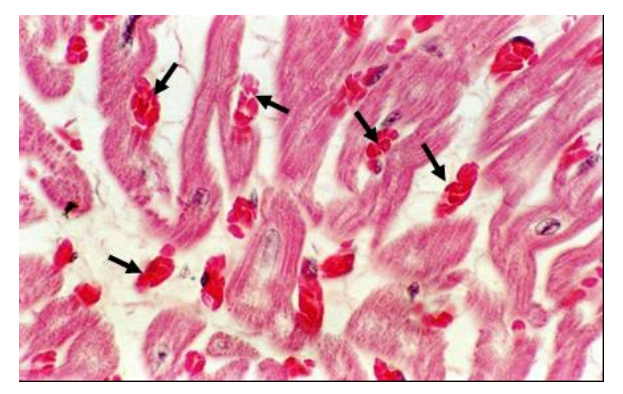

Figure 18. Hepatic cells degenerescence around the portal vein in camel receiving $16 \mathrm{mg} \mathrm{Se}$ /day (Seboussi, [42]).

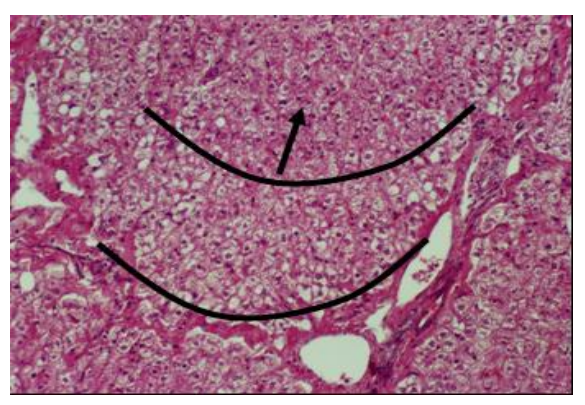

The clinical symptoms observed in camel were in accordance with previous signs reported in chronic poisoning in other species $[45,46]$. When selenosis injury occurred, the selenium accumulated mainly in the circulatory and respiratory system as well as in the organs of elimination [47]. These findings were in accordance with lesions observed in the heart, lung, liver, kidney and urinary bladder. After the liver, the kidney, particularly the cortex, retained the highest concentration followed by the 
glandular tissues, especially the pancreas and pituitary. This explained the high Se level in kidney, the lesions occurring in cortex and medulla, the degenerative changes and necrosis found in the current study. The gross and histologic lesions reported in camel were comparable to those observed in lambs [48] and suggest that the heart, as target organ of selenium intoxication, failed, leading to pulmonary edema and hydrothorax [49].

The foot lesions with the necrosis of keratonocytes were comparable to those observed in alkali disease (chronic selenosis) in cattle [50] and horse [51], despite the lack of hooves in camel.

Selenium deficiencies in animal, including camel, can result also in damages to the liver, heart, kidney and skeletal muscles [27,52]. So, comparable necropsy lesions were reported on Se deficiency and toxicity. The lack or the excess of selenium seems to lead to similar cell damage.

According to the recommendations for beef cattle [53], the minimum level of selenium in the diet that causes chronic selenosis in most animal species is $4-5 \mathrm{mg} / \mathrm{kg}$ of dry matter (DM) and the minimum level needed to prevent deficiency is $0.02-0.05 \mathrm{mg} / \mathrm{kg} \mathrm{DM}$. In the experimental selenosis described by Seboussi et al. [10], the first symptoms appeared with a diet containing $2.5 \mathrm{mg} / \mathrm{kg} \mathrm{DM}$ only. Chronic Se poisoning is not limited to grazing livestock and can occur from consumption of high Se intake in feed. For example, in the UAE, camels' owners supplement their animals to avoid deficiency with a commercial salt mixture and pharmaceutical form by drench or injection. However, no data on camel selenosis has been reported. The question of the poisoning threshold in camel has not been clearly determined. Oral ingestion of 1 to $2.2 \mathrm{mg}$ of Se/ $\mathrm{kg}$ life weight (LW) as sodium selenite has caused appreciable mortality in lambs up to 14 weeks of age [54], but individual susceptibility to selenosis could be highly variable. Tiwary et al. [48] did not observe lamb mortality with an oral sodium selenite up to $4 \mathrm{mg} / \mathrm{kg} \mathrm{LW}$. For other authors, the oral median lethal dose (LD50) of sodium selenite has been reported to be $1.9 \pm 1.2 \mathrm{mg}$ of Se/ $\mathrm{kg} \mathrm{LW}$ [49,55-58]. A daily intake of $0.25 \mathrm{mg} / \mathrm{kg}$ LW is considered as toxic for sheep and cattle [57]. Selenium poisoning was observed with diet containing $44 \mathrm{mg} / \mathrm{kg} \mathrm{DM}$ for horses and $11 \mathrm{mg} / \mathrm{kg} \mathrm{DM}$ for pig [57]. Typical lesions of chronic selenium toxicosis were observed on young cattle receiving more than $5 \mathrm{mg} / \mathrm{kg}$ DM for 120 days [50].

These levels listed previously are higher than the dietary levels in the studies performed on camel [10,13], i.e., 0.051 to $0.095 \mathrm{mg} / \mathrm{kg} \mathrm{LW}$ ), which seems to show a high sensitivity of camel species to Se toxicosis. The levels of selenium requirement and toxicity could be very close. For example, in intoxicated lambs with $4 \mathrm{mg} / \mathrm{kg} \mathrm{LW}$ under sodium selenite form (four times higher than the camels receiving $16 \mathrm{mg}$ Se daily in the trial of Seboussi et al. [11], the serum Se increased up to $274 \mathrm{ng} / \mathrm{mL}$ only [48], compared to $767 \mathrm{ng} / \mathrm{mL}$ observed in camel [11].

After one month supplementation with $12 \mathrm{ppm}$ Se in the diet, pregnant cattle showed Se values in serum above $420 \mathrm{ng} / \mathrm{mL}$ [58]. Higher values up to $1500 \mathrm{ng} / \mathrm{mL}$ were reported on large animals grazing on seleniferous pastures [51]. In lambs, with a diet containing $10 \mathrm{ppm}$ of selenium [48], no toxicity was observed after one year and the selenium values reached $0.39 \mathrm{ppm}$ in serum $(390 \mathrm{ng} / \mathrm{mL})$ after 12 weeks (comparatively to the results of Seboussi et al. [11]: after 90 days, $519 \pm 97 \mathrm{ng} / \mathrm{mL}$ for groups receiving $3.5 \mathrm{ppm}$ Se in the diet only). 


\section{Conclusions}

The metabolism of selenium in camel is quite comparable to that of the other herbivores, with similar diseases in case of deficiency or toxicosis, comparable values in serum and organs and comparable mode of excretion. However, some specificities could be observed: the richness of camel milk in selenium, the role of fecal excretion in case of intoxication, the apparent sensitivity to toxicity, and the high concentration in blood with high Se supplementation. According to dietary Se supply and mean weight of the animal, selenosis appeared with $0.05 \mathrm{mg} / \mathrm{kg}$ LW Se supply only. Severe intoxication occurred with $16 \mathrm{mg}$ Se supplementation, i.e., $0.10 \mathrm{mg} / \mathrm{kg} \mathrm{LW}$. These values were 5 times lower than those for sheep and cattle. Based on these results, it seems essential to limit Se supplementation in camel at $0.01-0.02 \mathrm{mg} / \mathrm{kg} \mathrm{LW}$, i.e., approximately 4-8 $\mathrm{mg}$ per day for adult animals or $0.5-1 \mathrm{ppm}$ in the diet.

\section{References}

1. Faye, B.; Bengoumi, M. Trace-elements status in camels: a review. Biol. Trace Element Res. 1994, 41, 1-11.

2. Faye, B.; Bengoumi, M. Adaptability of the dromedary camel to the mineral under-nutrition. In Proceedings of 27th World Veterinary Congress, Tunis, Tunisia, 25-29 September 2002, n142, 2002; p. 73.

3. Faye, B.; Bengoumi, M.; Tressol, J.C. Comparative trace-element excretion in camel and cow. J. Camel Res. Pract. 1999, 6, 19-25.

4. Faye, B.; Bengoumi, M. Comparative trace-element status in camel and cow. J. Camel Res. Pract. 1997, 4, 213-215.

5. El Khasmi, M.; Riad, F.; Safwate, A.; Farh, M.; Faye, B.; El Abbadi, N.; Lalaoui, Kh.; Coxam, V.; Davicco, M.J.; Barlet, J.P. Influence de la 1,25-dihydroxyvitamine $\mathrm{D}_{3}$ sur l'excrétion mammaire du calcium et du phosphore chez la chamelle allaitante. Rev. Elev. Med. Vét. Pays Trop. 2001, 54, 277-280.

6. Bengoumi, M.; Faye, B. Adaptation du dromadaire à la déshydratation. Rev. Sécheresse 2002, 13, 121-129.

7. Bengoumi, M.; Essamadi, A.K.; Chacornac, J.P.; Tressol, J.C.; Faye, B. Comparative relationship between copper-zinc plasma concentration and superoxide dismutase activity in camels and cow. Vet. Res. 1998a, 29, 557-565.

8. Essamadi, K.; Bengoumi, M.; Tressol, J.C.; Chacornac, J.P.; Faye, B. Comparative relationship of plasma copper concentration and ceruloplasmin activity of camel and cow. Trends Comp. Biochem. Physiol. 1998, 5, 211-220.

9. Seboussi, R.; Faye, B.; Alhadrami, G.; Askar, M.; Ibrahim,W.; Hassan, K.; Mahjoub, B. Effect of different selenium supplementation levels on selenium status in camel. Biol. Trace Elem. Res. 2008a, 123, 124-138.

10. Seboussi, R.; Alhadrami, G.; Askar, M.; Faye, B. Effect of excess selenium on dromedary camel in the United Arab Emirates. In Proceeding of the International Workshop - Impact of Pollution on Animal Products, Almaty, Kazakhstan, 27-30 September 2007; pp. 143-146. 
11. Seboussi, R.; Faye, B.; Askar, M.; Hassan, K.; Alhadrami, G. Effect of selenium supplementation on blood status and milk, urine and fecal excretion in pregnant and lactating camel. Biol. Trace Elem. Res. 2009a, 128, 45-57.

12. Seboussi, R.; Faye, B.; Alhadrami, G.; Askar, M.; Bengoumi, M.; Elkhouly, A. Chronic selenosis in camel. J. Camel Pract. Res. 2009b, in press.

13. Faye, B.; Seboussi, R. Experimental selenium intoxication in camel. Veterinaria 2008, 3, 18-29.

14. Maas, J.; Parish, S.M.; Hodgson, D.R. Nutritional myodegeneration, In Large Animal Internal Medicine; Smith, B.P., Ed.; CV Mosby Co: St Louis, MO, USA, 1990; pp. 1352-1357.

15. HamLiri, A.; Olson, W.G.; Johnson, D.W.; Kessabi, M. Evaluation of biochemical evidence of congenital nutritional myopathy in the two-week prepartum fetuses from selenium-deficient ewes. J. Am. Vet. Med. Assoc. 1990, 51, 1112-1115.

16. Liu, Z.P.; Ma, Z.; Zhang, Y.J. Studies on the relationship between sway disease of Bactrian camels and copper status in Gansu Province. Vet. Res. Comm. 1994, 18, 251-260.

17. Abdel Rahim, A.G. The relationship between whole blood selenium (Se) concentration and the activity of the seleno-enzyme, glutathione peroxidase (GSH-Px E.C.I.11.1.9) in camel (Camelus dromedarius). J. Arid Environ. 2005, 62, 359-362.

18. Ma, Z. Studies on sway disease of Chinese Bactrian camels. Epidemiological and aetiological aspects; International Foundation for Science Project: Stockholm, Sweden, 1995; p. 17.

19. Bengoumi, M.; Essamadi, A.K.; Tressol, J.C.; Charconac, J.P.; Faye, B. Comparative effect of selenium concentration and erythrocyte gluthatione peroxidase activity in cattle and camels. Anim. Sci. 1998b, 67, 461-466.

20. Nazifi, S.; Mansourian, M.; Nikhaval, B.; Razavi, S.M. The relationship between serum level of thyroid hormones, trace elements and antioxidant enzymes in dromedary camel (Camelus dromedarius). Trop. Anim. Health Prod. 2009, 41, 129-134.

21. Barri, M.E.S.; Al-Sultan, S.I. Studies on selenium and vitamin E status of young Megaheem dromedary camels at Al-Ahsa province. J. Camel Pract. Res. 2007, 14, 51-53.

22. Seboussi, R.; Faye, B.; Alhadrami, G. Facteurs de variation de quelques éléments trace (sélénium, cuivre, zinc) et d'enzymes témoins de la souffrance musculaire (CPK, ALT et AST) dans le sérum du dromadaire (Camelus dromedarius) aux Emirats Arabes Unis. Rev. Elev. Med. Vét. Pays Trop. 2004, 57, 87-94.

23. Herdt, T.H. Blood serum concentrations of selenium in female llamas (Lama glama) in relationship to feeding practices, region of united states, reproductive stage, and health of offspring. J. Anim. Sci. 1995, 73, 337-344.

24. Finlayson, R.; Keymer, I.F.; Manton, J.A. Calcific cardiomyopathy in young camels (Camelus spp.). J. Comp. Path. 1971, 81, 71-77.

25. Wisner, H.; Schotke, B. White muscle disease at The Hellabrun Zoo in Munich. Vet. Erkr. Zoo Wild Tunis 1975, 1, 717-720.

26. Decker, R.A; McDermid, A. Nutritional myopathy in young camel. J. Zoo Anim. Med. 1977, 8, 20-21.

27. El Khouly, A.A.; Abbas, T.A.; Moustafa, T. Myocardial dystrophy in camel calves in the United Arab Emirates (field cases). Emir. J. Agric. Sci. 2001, 13, 11-17. 
28. Al-Qarawi, A.A.; Abbas, B.; Haroun, E.M.; Mahmoud, O.M.; Al-Hawas, A. Clinicopathological investigation of Selenium responsive myopathy in young adult camels. J. Camel Pract. Res. 2001, 8, 23-27.

29. Al-Awadi, F.M.; Srikumar, I.S. Trace elements and their distribution in protein fractions of camel milk in comparison to other commonly consumed milks. J. Dairy Res. 2001, 68, 463-469.

30. Ceballos, A.; Sanchez, J.; Stryhn, H.; Montgomery, J.B.; Barkema, H.W.; Wichtel, J.J. Metaanalysis of the effect of oral selenium supplementation on milk selenium concentration in cattle. $J$. Dairy Sci. 2009, 92, 324-342.

31. Yagil, R.; Sod-Moriah, V.A.; Meyerstein, N. Dehydration and camel blood. I. Red blood cell survival in the one-humped camel (Camelus dromedarius). Am. J. Physiol. 1974, 226, 298-300.

32. Barri, M.E.S.; Al-Sultan, S.I. Studies on selenium and vitamin E status of young Megaheem dromedary camels at Al-Ahsa province. J. Camel Pract. Res. 2007, 14, 51-53.

33. Al-Senaidy, A.M. Tocopherols in camel's plasma and tissues. Int. J. Nutr. Res. 1996, 66, 210-216.

34. Mousa, H.M.; Omer, O.H.; Ali, B.H.; Al-Wabel, N.; Ahmed S.M. Antioxidant levels in tissues of young and adult camels (Camelus dromedarius). J. Physiol. Biochem. 2006, 62, 213-218.

35. Corbera, J.A.; Morales, M.; Pulido, M.; Montoya, J.A.; Gutierrez, C. An outbreak of nutritional muscular dystrophy in dromedary camels. J. Appl. Anim. Res. 2003, 23, 117-122.

36. Juniper, D.T.; Philipps, R.H.; Jones, A.K.; Bertin, G. Selenium supplementation of lactating dairy cows: effect on selenium concentration in blood milk, urine and faeces. J. Dairy Sci. 2006, 89, 3544-3551.

37. Leng, L.; Boldizarova, L.K.; Faix, S.; Kovac, G. The urinary excretion of selenium in sheep treated with a vasopressin analogue. Vet. Res. 2000, 31, 499-505.

38. Cristaldi, L.A.; McDowell, L.R.; Buergelt, C.D.; Davis, P.A.; Wilkinson, N.S.; Martin, F.G. Tolerance of inorganic selenium in wether sheep. Small Rum. Res. 2005, 56, 205-213.

39. Lomba, F.; Chaveaux, G.; Massip, A.; Bienfet, V. Problème du sélénium chez les ruminants: 2signification biologique des teneurs en sélénium des poils. Etudes de divers cas de carence. Ann. Med. Vét., 1973, 117, 481-490.

40. Perry, T.W.; Beeson, W.M.; Smith, W.H.; Mohler, M.T. Effect of supplemental Se on performance and deposit of Se in blood and hair of finishing beef cattle. J. Anim. Sci., 1976, 42, 192-195.

41. Combs, G.F.; Combs, S.B. The Role of Se in Nutrition; Academic Press: New York, NY, USA, 1986; p. 532.

42. Seboussi, R. Métabolisme du sélénium chez le dromadaire. Thèse en zootechnie. Centre international d'études supérieures en sciences agronomiques (Supagro) de Montpellier: Montpellier, France, 2008; p. 292.

43. Jenkins, K.J.; Hidiroglou, M. Tolerance of the preruminant calf for selenium in milk replacer. $J$. Dairy Sci. 1986, 69, 1865-1870.

44. Clark, R.F.; Strukle, E.; Williams, S.R.; Manoguerra, A.S. Selenium poisoning from a nutritional supplement. JAMA 1996, 275, 1087-1088.

45. Casteel, S.W.; Osweiler, G.D.; Cook, W.O.; Daniels, G.; Kadlec, R. Selenium toxicosis in swine. J. Amer. Vet. Med. Assoc. 1985, 186, 1084-1085. 
46. Harrison, L.H.; Colvin, M.; Stuart, B.P.; Sangster, L.T.; Gorgacz, E.J.; Gosser, H.S. Paralysis in swine due to focal symmetrical poliomalacia: possible selenium toxicosis. Vet. Pathol. 1983, 20, 265-273.

47. Beath, O.A. The story of selenium in Wyoming. Bulletin 774, Agricultural Experiment Station University of Wyoming: Laramie, WY, USA, 1982; p. 32.

48. Tiwary, A.K.; Stegelmeier, B.M.; Panter, K.E.; James, L.F.; Hall, J.O. Comparative toxicosis of selenium selenite and sélénométhionine in lambs. J. Vet. Diagn. Invest. 2006, 18, 61-70.

49. Lambourne, D.A.; Mason, R.W. Mortality in lambs following with sodium selenite. Aust. Vet. J. 1969, 45, 208.

50. O'Toole, T.; Raisbeck, M.F. Pathology of experimentally induced chronic selenosis (alkali disease) in yearling cattle. J. Vet. Diagn. Invest. 1995, 7, 364-373.

51. Raisbeck, M.F.; Dahl, E.R.; Sanchez, D.A.; Belden, E.L.; O’Toole, D. Naturally occurring selenosis in Wyoming. J. Vet. Diagn. Invest. 1993, 5, 84-87.

52. Hammond, P.B.; Beliles, R.P. Metals. In Toxicology, the basic Science of poisons; 2nd ed.; Doull, J., Klaassen, C.D., Amdur, M.O., Eds.; McMillan Publications: New York, NY, USA, 1980; pp. 409-467.

53. National Research Council (NRC). Selenium requirements. In Nutrient Requirements of Beef Cattle; 7th, ed.; National Academies Press: New York, NY, USA, 2000; pp. 67-68.

54. Gabbedy, B.J. Toxicity in sheep associated with the prophylactic use of selenium. Aust. Vet. J. 1970, 46, 223-226.

55. Caravaggi, C.; Clark, F.L.; Jackson, A.R.B. Experimental acute toxicity of orally administrated sodium selenite in lambs. Res. Vet. Sci. 1970, 11, 146-149.

56. Blodgett, D.J.; Bevill, R.F. Acute selenium toxicosis in sheep. Vet. Human Toxicol. 1987, 29, 233-236.

57. Muth, O.H.; Binns, W. Selenium toxicity in domestic animals. Ann. N. Y. Acad. Sci. 1964, 111, 583-590.

58. Yaeger, M.J.; Neiger, R.D.; Holler, L.; Fraser, T.L.; Hurley, D.J.; Palmer, I.S. The effect of subclinical selenium toxicosis on pregnant beef cattle. J. Vet. Diagn. Invest. 1998, 10, 268-273.

(C) 2009 by the authors; licensee Molecular Diversity Preservation International, Basel, Switzerland. This article is an open-access article distributed under the terms and conditions of the Creative Commons Attribution license (http://creativecommons.org/licenses/by/3.0/). 